\title{
Chemical and Mineral Composition of Four Cultivars of Banana (Musa sp.) Belonging to Different Genomic Groups Grown in India
}

\author{
C.K. Narayana ${ }^{1 *}$, K.J. Jeyabaskaran ${ }^{2}$ and M.M. Mustaffa ${ }^{2}$ \\ ${ }^{1}$ Division of Post-Harvest Technology, ICAR-Indian Institute of Horticultural Research, \\ Hesarghatta Lake (P.O.), Bengaluru- 560 089, Karnataka, India \\ ${ }^{2}$ ICAR-National Research Centre for Banana, Thogamalai Road, Thayanur Post, \\ Tiruchirapalli - 620 102. Tamil Nadu, India \\ *Corresponding author
}

A B S T R A C T

Banana is an important food crop after rice, wheat and maize in several tropical and subtropical regions of the world. During the course of natural evolution, two seeded diploid species of banana (Musa acuminate - AA and Musa balbisiana - BB) hybridized naturally and developed into several genomic groups of seedless diploids and triploids (AA, AB, AAA, AAB, ABB) that are commercially cultivated. A study was conducted to investigate the chemical and mineral composition of cultivars belonging to four different genomic groups. Results revealed that B genome rich cultivar, Karpuravalli (ABB), had higher dry matter and starch, less moisture, total soluble solids, titratable acidity, total and reducing sugars, when compared with A genome rich cultivar, Robusta (AAA) and Poovan (AAB). Similarly cultivars with B genome had higher nitrogen, lesser calcium, potassium, zinc and iron, while mixed influence was noticed with regard to minerals like phosphorus and magnesium. From nutritional point of view, cultivars B genome cultivars (like Karpuravalli) can be considered as good source of carbohydrates and proteins, while A genome rich cultivar (like Robusta) are good source of important minerals, like potassium, calcium, magnesium, zinc and iron. Results of the present study could help food technologists in selecting trait specific cultivars of banana while designing functional foods for specific target groups.

\section{Introduction}

Banana is an important food crop after rice, wheat and maize in several tropical and subtropical regions of the world, serving both as staple food and dessert fruit. During the recent past, there is great interest among nutritionists and epidemiologists in studying the role of fruits and vegetables in prevention of several life style diseases. Beneficial effects of consumption of bananas include prevention of constipation, hypertension, cancer, etc., due to high level of fruit fibres, phytochemicals (carotenoids, anthocyanins, antioxidants) and vitamins and hence are considered as functional food (VergaraValencia et al., 2007). Bananas are also rich source of minerals like potassium, phosphorus, calcium, magnesium, zinc and iron. During the course of their natural evolution, two seeded diploid species of banana (Musa acuminate - AA and Musa 
balbisiana - BB) hybridized naturally and developed into several genomic groups of seedless diploids and triploids (AA, AB, AAA, AAB, ABB). Traits like chemical composition and the nutritional value of banana vary depending on several factors, such as genomic group, cultivar, climatic conditions of the growing area, soil composition and production practices (Arvanitoyannis and Mavromatis, 2009). In India, four major banana cultivars belonging to four distinct genomic groups viz., AB (Ney Poovan or Elakki), AAA (Robusta, Grand Naine, Tella Chakrakeli), AAB (Mysore or Poovan, Rasthali, Nendran) and ABB (Karpuravalli, Monthan) are widely cultivated. In the present investigation, a comprehensive study of chemical (moisture, total soluble solids, titratable acidity, sugars, and starch) and mineral composition (nitrogen, phosphorus, potassium, calcium, magnesium, sodium, iron, manganese, copper and zinc) of four cultivars (Neypoovan, Robusta, Poovan and Karpuravalli) belonging to four different genomic groups was carried out to see if genomic status could be an indicator for selecting a cultivar with desired nutritional quality.

\section{Materials and Methods}

Four banana cultivars, viz. Ney Poovan (AB), Robusta (AAA), Poovan (AAB) and Karpuravalli (ABB) were grown in the experimental farm of ICAR-National Research Centre for Banana (NRCB), Tiruchirapalli, Tamil Nadu state (India) adopting uniform cultivation practices. Five fully matured bunches of each cultivar were harvested, and after bringing to the laboratory they were dehanded, washed and dried under shade to remove surface moisture. Five hands were randomly picked from each cultivar and further separated into fingers.

About 20 fingers having uniform size and shape were selected from the above lot and blanched in hot water $\left(80-90^{\circ} \mathrm{C}\right)$ for $15-20$ minutes to facilitate easy peeling. A homogenous composite sample from 10 fingers was made after blanching and peeling the fruits and their physico-chemical parameters like moisture, total soluble solids, titratable acidity, sugars and starch were determined on fresh weight basis. Ten fingers from the blanched and peeled fruits were also sliced into round disks using a kitchen knife. These slices were dried in an hot air oven at $65 \pm 3^{\circ} \mathrm{C}$ for 8 hours. The dried slices were ground into fine powder using a laboratory mixer/grinder. The flour was then used for estimation of minerals (nitrogen, phoshphorus, potassium, calcium, magnesium, sodium, iron, manganese and zinc) as per the procedure detailed below.

\section{Estimation of chemical composition}

The moisture in the fresh sample was determined by drying a known weight of composite sample $(10 \mathrm{~g})$ in a hot air oven at $70^{\circ} \mathrm{C}$ till it reached a constant weight. The per cent moisture content was calculated using the formula $W_{1}-W_{2} / W_{1} \times 100\left(W_{l^{-}}\right.$initial weight, $W_{2}$ final weight). The total soluble solids were recorded using a hand refractometer $\left(0-32^{\circ}\right.$ range; Erma make, Japan) and the values were expressed in ${ }^{\circ}$ Brix. The titratable acidity and sugars were determined by the standard methods suggested by Ranganna (1986) and starch by anthrone reagent method (Hedge and Hofreiter, 1962). Each analysis was done using three replicates and the values were expressed on fresh weight basis.

\section{Estimation of minerals}

The dried banana powder prepared from the above four cultivars was used for determination of minerals. The nitrogen content in these cultivars was analysed by Kjeldahl method as outlined by Piper (1966) and the values were expressed in $\mathrm{g} / 100 \mathrm{~g}$. For 
estimation of $\mathrm{P}, \mathrm{K}, \mathrm{Na}, \mathrm{Ca}, \mathrm{Mg}, \mathrm{Fe}, \mathrm{Cu}, \mathrm{Mn}$ and $\mathrm{Zn}$, the powdered samples were digested in Tri-acid (Nitric acid, Sulphuric acid, Perchloric acid in a ratio of 7:9:2) and in the digested samples, phosphorus content was determined by Vanadomolybdate method (Piper, 1966), potassium and sodium content by flame photometer method (Piper, 1966), while the calcium and magnesium were analyzed by adopting Versenate titration method (Piper, 1966) and values were expressed in g/100g. The iron, copper, manganese and zinc were determined by using the Atomic Absorption Spectrometer and values were expressed in parts per million (ppm). Each analysis was done using three replicates and the values were expressed on dry weight basis. The data was subjected to ANOVA to see the significance of variance between cultivars.

\section{Results and Discussion}

\section{Effect of genomic status on physico-} chemical composition of fruits

In the present study, all physico-chemical constituents and mineral composition were analysed only at unripe stage (Table 1). The moisture content of banana cultivars of different genomic groups ranged from $62.70 \pm 0.57$ to $78.34 \pm 0.39 \%$. The moisture content of fruits also indicated that dry matter accumulated in the fruit during its growth and development. As all the cultivars were grown in the same location adopting similar cultivation practices, the variation in the moisture content can be attributed to their genomic constitution. The cultivar Robusta (AAA Cavendish group- Musa acuminata) recorded the maximum moisture content $(78.34 \pm 0.39 \%)$ followed by Ney Poovan (AB) $(70.80 \pm 0.22 \%)$. Poovan (AAB) and Karpuravalli (ABB) (Pisang Awak type) cultivars had a moisture content of $70.07 \pm 0.33$ and $62.70 \pm 0.57 \%$ respectively. It is evident from the results that $\mathrm{A}$ genome rich cultivars was found to have more moisture and less dry matter or B genome rich cultivars were more starchy with less moisture. Similar results were observed on chemical composition of various banana cultivars grown in Canary Islands, Ecuador and Africa (Arvanitoyannis \& Mavrotomis, 2009).

The level of total soluble solids was highest $\left(4.82 \pm 0.02^{\circ}\right.$ Brix) in cultivar Poovan (AAB) followed by $4.68 \pm 0.05,3.00 \pm 0.08$ and $2.96 \pm 0.05^{\circ}$ Brix in Ney Poovan (AB), Robusta (AAA) and Karpuravalli (ABB) respectively. The trend in this study indicated that at full mature stage, the cooking types or B genome rich cultivars are more starchy compared to dessert types (AAA sub-group).

Therefore, A genome rich cultivars had higher total soluble solids. Poovan (Mysore subgroup-AAB), also called Champa in several parts of India, is slightly sour compared to others among dessert types. Poovan (AAB) banana had the highest titratable acidity $(0.20 \pm 0.01 \%)$ followed by Ney Poovan (AB), Robusta (AAA) and Karpuravalli (ABB), respectively. Similar observations were registered in terms of $\mathrm{pH}$ (Dadzie, 1998) in upland bananas grown in Africa.

The total sugar content was highest $(1.05 \pm 0.04 \%)$ in cultivar Poovan (AAB) followed by Ney Poovan (AB), Robusta (AAA), and Karpuravalli (ABB). The commercial maturity index is based on morphological appearance, though the fruits could be at different stages of physiological maturity based on its internal biochemical status. Among sugars, the reducing sugars were highest in Poovan (AAB), followed by Karpuravalli (ABB), Ney Poovan (AB) and Robusta (AAA). The concentration of sugars also varied with level of maturity. The starch content was highest $(31.47 \pm 0.41$ per cent) in cultivar Karpuravalli (ABB) followed by Poovan (AAB), Ney Poovan (AB), and Robusta (AAA). 
Table.1 Physico-chemical composition of different genomic sub-groups of banana (Fresh weight basis)

\begin{tabular}{|c|c|c|c|c|c|c|}
\hline Varieties & $\begin{array}{l}\text { Moisture } \\
(\%)\end{array}$ & $\begin{array}{l}\text { Total } \\
\text { Soluble } \\
\text { Solids } \\
\left({ }^{\circ} \text { Brix }\right)\end{array}$ & $\begin{array}{l}\text { Acidity } \\
(\%)\end{array}$ & $\begin{array}{l}\text { Total } \\
\text { Sugars } \\
(\%)\end{array}$ & $\begin{array}{l}\text { Reducing } \\
\text { Sugars }(\%)\end{array}$ & $\operatorname{Starch}(\%)$ \\
\hline $\begin{array}{l}\text { Robusta } \\
\text { (AAA sub-group) }\end{array}$ & $78.34 \pm 0.39$ & $3.00 \pm 0.08$ & $0.11 \pm 0.01$ & $0.77 \pm 0.01$ & $0.19 \pm 0.01$ & $18.60 \pm 0.38$ \\
\hline $\begin{array}{l}\text { Ney Poovan } \\
\text { (AB sub-group) }\end{array}$ & $70.80 \pm 0.22$ & $4.68 \pm 0.05$ & $0.16 \pm 0.01$ & $0.80 \pm 0.01$ & $0.29 \pm 0.01$ & $22.33 \pm 0.30$ \\
\hline $\begin{array}{l}\text { Poovan } \\
\text { (AAB sub-group) }\end{array}$ & $70.07 \pm 0.33$ & $4.82 \pm 0.02$ & $0.20 \pm 0.01$ & $1.05 \pm 0.04$ & $0.61 \pm 0.01$ & $22.85 \pm 0.26$ \\
\hline $\begin{array}{l}\text { Karpuravalli } \\
\text { (ABB sub-group) }\end{array}$ & $62.70 \pm 0.57$ & $2.96 \pm 0.05$ & $0.08 \pm 0.01$ & $0.60 \pm 0.02$ & $0.45 \pm 0.01$ & $31.47 \pm 0.41$ \\
\hline
\end{tabular}

Table.2 Mineral composition of different genomic sub-groups of banana (Dry weight basis)

\begin{tabular}{|c|c|c|c|c|c|c|c|c|c|c|}
\hline Varieties & $\begin{array}{l}\mathbf{N} \\
(\mathrm{g} / 100 \mathrm{~g})\end{array}$ & $\begin{array}{l}\mathbf{K} \\
(\mathrm{g} / 100 \mathrm{~g})\end{array}$ & $\begin{array}{l}\mathbf{P} \\
(\mathrm{g} / 100 \mathrm{~g})\end{array}$ & $\begin{array}{l}\mathbf{C a} \\
(\mathrm{g} / 100 \mathrm{~g})\end{array}$ & $\begin{array}{l}\mathbf{M g} \\
(\mathrm{g} / 100 \mathrm{~g})\end{array}$ & \begin{tabular}{|l}
$\mathbf{N a}$ \\
$(\mathrm{g} / 100 \mathrm{~g})$
\end{tabular} & \begin{tabular}{|l|}
$\mathbf{C u}$ \\
$(\mathrm{ppm})$
\end{tabular} & \begin{tabular}{|l}
$\mathbf{F e}$ \\
$(\mathrm{ppm})$
\end{tabular} & $\mathbf{Z n}(\mathrm{ppm})$ & $\begin{array}{l}\text { Mn } \\
(\mathrm{ppm})\end{array}$ \\
\hline $\begin{array}{l}\text { Robusta } \\
\text { (AAA) }\end{array}$ & $0.35 \pm 0.01$ & $1.70 \pm 0.07$ & $0.10 \pm 0.01$ & $0.40 \pm 0.04$ & $0.24 \pm 0.02$ & $0.20 \pm 0.01$ & 0 & $\begin{array}{l}263 \pm 2.4 \\
5\end{array}$ & $289 \pm 3.27$ & $14 \pm 1.41$ \\
\hline $\begin{array}{l}\text { Ney Poovan } \\
(\mathrm{AB})\end{array}$ & $0.35 \pm 0.01$ & $1.30 \pm 0.04$ & $0.06 \pm 0.01$ & $0.80 \pm 0.03$ & $0.48 \pm 0.01$ & $0.20 \pm 0.02$ & 0 & $25 \pm 9.27$ & $236 \pm 5.89$ & $26 \pm 0.82$ \\
\hline $\begin{array}{l}\text { Poovan } \\
(\mathrm{AAB})\end{array}$ & $0.29 \pm 0.01$ & $1.30 \pm 0.04$ & $0.10 \pm 0.01$ & $0.80 \pm 0.03$ & $0.44 \pm 0.02$ & $0.20 \pm 0.01$ & 0 & \begin{tabular}{|l|}
$221 \pm 0.8$ \\
2 \\
\end{tabular} & $338 \pm 1.63$ & $13 \pm 0.82$ \\
\hline $\begin{array}{l}\text { Karpuravalli } \\
(\mathrm{ABB})\end{array}$ & $0.58 \pm 0.02$ & $1.10 \pm 0.08$ & $0.09 \pm 0.01$ & $0.80 \pm 0.08$ & $0.24 \pm 0.02$ & $0.20 \pm 0.02$ & 0 & $\begin{array}{l}138 \pm 1.4 \\
2\end{array}$ & $255 \pm 3.56$ & $12 \pm 1.41$ \\
\hline
\end{tabular}


This data again supports the earlier inference that $\mathrm{B}$ genome rich cultivars have higher starch compared to A genome rich ones. However, after ripening when the starch gets converted to sugars, the B genome rich cultivars exhibited highest level of sugars (Narayana et al., 2002) which is due to the hydrolysis of starch.

\section{Effect of genomic status on mineral composition of fruits}

The cultivar Karpuravalli (Pisang Awak, ABB sub-group) had significantly higher levels of nitrogen content $(0.58 \pm 0.02 \%)$, compared to Robusta (AAA) and Ney Poovan (AB) $(0.35 \pm 0.01 \%$ each $)$ and the least was in Poovan (AAB) $(0.29 \pm 0.01 \%)$. This may be due to higher level of nitrogen uptake (both through soil and bunch feeding) as reported earlier (Kotur and Murthy, 2011; Yang et al., 2013).

Potassium level was highest in cultivar Robusta $(1.70 \pm 0.07 \%)$ followed by Ney Poovan and Poovan $(1.30 \pm 0.04 \%$ each $)$ and lowest potassium was found in cultivar Karpuravalli $(1.10 \pm 0.01 \%)$. Differential response of bananas belonging to different genomic groups to potassic fertilizers in terms of quality has already been reported by Weerasinghe and Premlal (2002). Besides genomic status, the soil and climatic conditions also play an important role in nutrient uptake.

Phosphorus helps plants to store and use energy from photosynthesis, develop roots, speed-up the maturity, and resist stresses. In the present investigation, Karpuravalli (ABB), Robusta (AAA) and Poovan (AAB) cultivars of banana did not exhibit significant variation in their levels of phosphorus $(0.09 \pm 0.01$ to $0.10 \pm 0.01 \%)$ while Ney Poovan (AB) had the least $(0.06 \pm 0.01 \%)$ level of phosphorus. This is in conformity with previous findings of Sulaiman et al., (2011) who studied the phosphorus content of banana cultivars grown in Malaysia.

The level of calcium was similar $(0.80 \pm 0.03 \%)$ in cultivars Ney Poovan (AB), Poovan (AAB) and Karpurvalli (ABB) while it was significantly lower $(0.40 \pm 0.04 \%)$ in Robusta (AAA group). These values though are considerably higher than those reported by Sulaiman et al., (2011), it clearly indicated that cultivars with B genome tend to absorb and assimilate more calcium than $\mathrm{A}$ genome rich cultivars. Besides the genomic constitution, other factors like soil $\mathrm{pH}$ and other competitive inhibitors also affect the nutrient uptake (Sulaiman et al., 2011).

Among the secondary macronutrients, magnesium is abundantly available in banana fruits (Sulaiman et al., 2011 and Deshmukh et al., 2009). Cultivars Ney Poovan (AB) and Poovan (AAB) had high levels of magnesium $(0.48 \pm 0.01 \%$ and $0.44 \pm 0.02 \%$ respectively) compared to Robusta (AAA) and Karpuravalli (ABB) $(0.24 \pm 0.02 \%$ each). Contrary to the findings of Deshmukh et al., (2009) and Sulaiman et al., (2011), the level of magnesium in cultivars of $\mathrm{ABB}$ and $\mathrm{AAB}$ genomic group was lower than those of $\mathrm{AAA}$ or $\mathrm{AB}$ group. There was no significant difference in the sodium content among different varieties. Influence of genomic status on magnesium uptake and utilization vis-a-vis the soil condition and microflora needs critical investigation.

Bananas are good source of iron and zinc, the two micronutrients essential for plant and human health. Among cultivars studied Robusta (AAA), Poovan (AAB) and Karpuravalli (ABB) bananas had higher levels of iron compared to Ney Poovan. These findings are in conformity with reports of earlier workers (Deshmukh et al., 2009; Sulaiman et al., 2011). Zinc ranged of $236 \pm 5.89$ to $338 \pm 1.63 \mathrm{ppm}$ in different cultivars with Poovan ( $\mathrm{AAB}$ sub-group) exhibiting the highest zinc content followed by Robusta (AAA sub-group). The genomic influence on the zinc content could not be related. Manganese was in the range of $12 \pm 1.41$ to $26 \pm 0.82 \mathrm{ppm}$, with the highest in Ney Poovan (AB-diploid), and triploids did not vary significantly in their manganese content. No detectable level of copper was noticed in any of the cultivars studied. 
In general, the average values of $\mathrm{Ca}, \mathrm{Mg}, \mathrm{Fe}$ and $\mathrm{Zn}$ contents were higher than those reported in the literature, which may be due to the influence of banana cultivars grown in India and/or other factors such as soil, climate, cultural practices and the quality of water used for irrigation.

The results indicated that $\mathrm{B}$ genome rich varieties are rich in starch and proteins, while A genome rich varieties are good source of important minerals like potassium, calcium, zinc and iron. Phosphorus and magnesium were not significantly influenced by genomic status (A or B) of different varieties of bananas cultivated in India. These findings may help food technologists in selecting trait specific banana cultivar while designing functional foods for specific target groups.

\section{Acknowledgement}

The authors acknowledge the financial support by Indian Council of Agricultural Research, New Delhi and the technical assistance provided by Mr. K. Kamaraju and Ms. Anithasree Murugan during the course of investigation.

\section{References}

Arvanitoyannis, I. S., and A. Mavromatis. 2009. Banana Cultivars, Cultivation Practices, and Physicochemical Properties. Crit Rev Food Sci. 49 (2): 113-135.

Dadzie, B. K., 1998. Post-harvest characteristics of black Sigatoka resistant banana, cooking banana and plantian hybrids. International Network for the Improvement of Banana and Plantain, Montpellier, France, pp. 98-112.
Deshmukh, M.H., Pai, S.R., Nimbalkar, M, S. and Patil, R.P. 2009. Biochemical characterization of banana cultivars from southern India. Int J Fruit Sci. 9(4):305322.

Hedge, J. E., and Hofreiter, B. T. 1962. Methods of estimating starch and carbohydrates. In: Carbohydrate Chemistry (Eds. Whistler, R. L. and Be Miller, J. N.). Academic Press, New York. pp: 17-26.

Kotur, S.C., and Keshava Murthy, S.V. 2011. Enhancing the fruit yield of 'Robusta' banana (Musa paradisiaca) by denavelling and feeding nitrogen, potassium and sulphur through the distal stalk-end of the bunch. Indian J Agr Sci. [S.1], v.78, n.2, 2011. ISSN 0019-5022.

Narayana, C.K., Mustaffa, M.M. and Sathiamoorthy, S. 2002. Effect of packaging and storage on shelf life and quality of banana cv. Karpuravalli. Indian J Hort. 59(2): 113-117.

Piper, C.S., 1966. Soil and Plant Analysis. Hans Publishers. Bombay.

Ranganna, S., 1986. Handbook of analysis and quality control for fruit and vegetable products, Second edn, Tata McGraw-Hill Pub. Co, New Delhi, India, pp.9-20.

Sulaiman, S.F., Nor Adlin Md. Y., Ibrahim M.Eldeen, Eng M, S., Azliana A.B.S., Supriatno, K.L.O. 2011. Correlation between total phenolic and mineral contents with antioxidant activity of eight Malaysian bananas (Musa sp.). J Food Compost Anal. 24: 1-10.

Weerasinghe, P., and Premalal, N.H.R. 2002. Influence of potassium fertilization of growth and yield of Embul Banana (Musa spp. AAB Group) grown in Rhodudalfs under irrigated conditions. Annal. Sri Lanka Dep. Agric., 4:109-117.

\section{How to cite this article:}

Narayana, C.K., K.J. Jeyabaskaran and Mustaffa, M.M. 2017. Chemical and Mineral Composition of Four Cultivars of Banana (Musa sp.) Belonging to Different Genomic Groups Grown in India. Int.J.Curr.Microbiol.App.Sci. 6(9): 2862-2867. doi: https://doi.org/10.20546/ijcmas.2017.609.351 